\title{
HISTOLOGICAL MARKERS OF DEGENERATION AND REGENERATION OF THE HUMAN INTERVERTEBRAL DISK
}

\author{
MARCADORES HISTOLÓGICOS DE DEGENERAÇÃO E REGENERAÇÃO DO DISCO \\ INTERVERTEBRAL HUMANO
}

\section{MARCADORES HISTOLÓGICOS DE LA DEGENERACIÓN Y REGENERACIÓN DEL DISCO INTERVERTEBRAL HUMANO}

\author{
Manuela Peletti-Figueiró ${ }^{1,5}$, Israel Silveira de Aguiar ${ }^{1}$, Suelen Paesi ${ }^{2}$, Denise Cantarelli Machado ${ }^{3}$, Sergio Echeverrigaray ${ }^{4}$, Mariana Roesch-Ely ${ }^{1}$, \\ Asdrubal Falavigna ${ }^{5}$, João Antonio Pêgas Henriques' \\ 1. Universidade de Caxias do Sul (UCS), Instituto de Biotecnologia, Laboratório de Genômica, Proteômica e Reparo DNA. Caxias do Sul, RS, Brazil. \\ 2. Universidade de Caxias do Sul (UCS), Instituto de Biotecnologia, Laboratório de Diagnóstico Molecular. Caxias do Sul, RS, Brazil. \\ 3. Pontifícia Universidade Católica do Rio Grande do Sul (PUCRS), Instituto de Pesquisas Biomédicas, Laboratório de Biologia Celular e Molecular e Centro de Terapia Celular. \\ Porto Alegre, RS, Brazil. \\ 4. Universidade de Caxias do Sul (UCS), Instituto de Biotecnologia, Laboratório de Microbiologia Aplicada, Caxias do Sul, RS, Brazil. \\ 5. Universidade de Caxias do Sul (UCS), Laboratório de Terapia Celular, Caxias do Sul, RS, Brazil.
}

\begin{abstract}
Objective: To define histological scores for intervertebral disc degeneration that would enable the definition of morphological characteristics of disease, besides improving knowledge of the lumbar degenerative disc disease by means of immunohistochemical markers. Methods: Hematoxylin and Eosin, Alcian/PAS, Masson Trichrome and Safranin O/FCF staining was used on the intervertebral disc degeneration sections of patients with lumbar degenerative disc disease. The protein markers defined in immunohistochemistry were cell proliferation (Ki-67) and apoptosis (p53). Results: The study data enabled the determination of Safranin O/FCF stain as the most effective one for evaluating parameters such as area, diameter, and number of chondrocyte clusters. The importance of using stains in association, such as Safranin O/FCF, Masson Trichrome, Alcian/PAS and Hematoxylin and Eosin, was also determined, as they are complementary for the histopathological verification of intervertebral disc degeneration. By expressing proteins using the immunohistochemistry technique, it was possible to consider two stages of disc degeneration: cell proliferation with chondrocyte cluster formation, and induction of apoptosis. Conclusion: This study enabled the histological and immunohistochemical characterization to be determined for lumbar degenerative disc disease, and its degrees of evolution, by determining new disc degeneration scores.
\end{abstract}

Keywords: Intervertebral disc; Histology; Immunohistochemistry; Cell proliferation; Apoptosis.

\section{RESUMO}

Objetivo: Definir escores histológicos de degeneração do disco intervertebral que permitam a identificação de características morfológicas da doença, além de melhorar o conhecimento sobre a discopatia degenerativa lombar por meio de marcadores imuno-histoquímicos. Métodos: As colorações histológicas de hematoxilina e eosina, azul de alcian/PAS, tricrômica de Masson e safranina O/FCF foram utilizadas em cortes de disco intervertebral degenerado de pacientes com discopatia degenerativa lombar. Os marcadores proteicos definidos na imuno-histoquímica permitiram a avaliação da proliferação celular (Ki-67) e da apoptose (p53). Resultados: Os dados do estudo permitiram a determinação da coloração de safranina O/FCF como a mais eficaz para avaliar os parâmetros tais como a área, o diâmetro e o número de agrupamentos de condrócitos. Também se determinou a importância do uso das colorações histológicas de forma associada, como safranina O/FCF, tricrômica de Masson, azul de alcian/PAS e hematoxilina e eosina, uma vez que elas são complementares para a verificação histopatológica da degeneração do disco intervertebral. Pela técnica da expressão de proteínas com técnica imuno-histoquímica, foi possível considerar dois estágios de degeneração do disco: proliferação de células com a formação de agrupamentos de condrócitos, seguida pela indução de apoptose. Conclusão: Este estudo permitiu definir a caracterização histológica e imuno-histoquímica em discopatia degenerativa lombar e seus graus de evolução, determinando novos escores de degeneração discal.

Descritores: Disco intervertebral; Histologia; Imuno-histoquímica; Proliferação celular; Apoptose.

\section{RESUMEN}

Objetivo: Definir valores histológicos de degeneración del disco intervertebral que permitan la definición de las características morfológicas de la enfermedad y mejorar el conocimiento de la enfermedad degenerativa del disco lumbar mediante marcadores inmunohistoquímicos. Métodos: Las coloraciones histológicas con hematoxilina y eosina, azul alcián/PAS, tricrómico de Masson y safranina O/FCF se utilizaron en secciones de los discos intervertebrales degenerados de pacientes con enfermedad degenerativa del disco lumbar. Los marcadores de proteínas definidos por inmunohistoquímica permitieron la evaluación de la proliferación celular (Ki-67), y la apoptosis (p53). Resultados: Los datos de la determinación permitieron establecer la tinción con safranina O/FCF como la más eficaz para evaluar parámetros tales como el área, diámetro y número de agrupaciones de condrocitos. Se determinó también la importancia del uso asociado de diversas tinciones, como safranina O/FCF, tricrómico de Masson, azul de alcián/PAS y hematoxilina y eosina, ya que son complementarias para la verificación histopatológica de la degeneración del disco intervertebral. Por la técnica de la expresión de proteína con análisis inmunohistoquímica, fue 
posible establecer dos etapas de la degeneración del disco: la proliferación de células con la formación de agrupaciones de condrocitos y la inducción de la apoptosis. Conclusión: Este estudio permitió definir la caracterización histológica e inmunohistoquímica en la enfermedad degenerativa del disco lumbar y sus grados de evolución, mediante la determinación de nuevas puntuaciones de degeneración del disco.

Descriptores: Disco intervertebral; Histología; Inmunohistoquímica; Proliferación celular; Apoptosis.

\section{INTRODUCTION}

The intervertebral disc (IVD) is the spine structure responsible for the daily absorption of load and impact on the human body. The IVD is comprised of the annulus fibrosus (AF) and nucleus pulposus (NP), and its dysfunction often causes painful back symptoms. Disc degeneration is considered a natural process of human senescence, but at advanced stages, besides back pain, it can trigger irradiated pain to the upper or lower limbs due to compression of the spinal nerve, further compromising the patients' quality of life and causing great social and economic losses. ${ }^{1-6}$

Histological degeneration of the IVD is initially identified in the first years of adolescence. The NP and AF contain an abundant amount of extracellular matrix, consisting mainly of proteoglycans and collagens. ${ }^{7}$

When the number of chondrocytes in adult cells of the NP increases, they may modify the notochord phenotype and trigger a cell reduction due to the high levels of apoptosis. ${ }^{8,9}$ The mature NP in the presence of lumbar degenerative disc disease (LDD) provokes a hyaline formation in the cartilage, expressing high levels of markers for the chondrocytes, which enable the verification and follow-up of disc degeneration. ${ }^{10,11}$ The painful symptoms of disc degeneration are a result of loss of functionality and mechanical integrity of the disc. These are direct consequences of qualitative and quantitative histological changes of the proteoglycans, collagens, proportion of water, cell proliferation, and increase in dead cells. ${ }^{5,12,13}$

Multiple factors are responsible for IVD degeneration, which may be influenced by biomechanical characteristics, genetic interaction, biocellular modifications and environmental variations. ${ }^{6}$

In the last few years, studies have been conducted on cell proliferation proteins and apoptosis, seeking to identify IVD degeneration. ${ }^{14-17}$ The use of these protein markers allows the study of two phases of disc degeneration: in the first phase, there is an attempt to revitalize the disc tissue, with proliferation and increased cell mass with high Ki-67 expression, resulting in the formation and increase of chondrocyte clusters; in the second phase, there is more marked degeneration, and apoptosis of the chondrocyte clusters in $\mathrm{NP}$ is seen through increased levels of p53 protein expression. ${ }^{5}$

The objective of this work is to determine the histological changes and their clinical-radiological correlation, through the definition of new disc degeneration scores. This study also attempts to determine IVD degeneration through the stages of cell proliferation and apoptosis.

\section{METHODS}

\section{Study sample}

The study allocated patients with pain symptoms in the lumbar region and/or lower limbs refractory to conservative treatment with analgesia, anti-inflammatories, or physiotherapy. The patients underwent radiological diagnosis of disc degeneration disc disease by simple $\mathrm{X}$-ray and magnetic resonance imaging (MRI) of the lumbar spine. After 12 weeks of failed conservative treatment, surgical treatment was suggested, in order to perform nerve decompression, either with or without instrumented fusion. The inclusion criteria were degenerative pathology of the lumbar spine, refractoriness to conservative treatment, clinical and radiological agreement, and agreeing to participate in the study by signing an informed consent form.

The exclusion criterion was prior surgery. The controls used were the lumbar intervertebral discs obtained from patients with diagnosis of idiopathic thoracolumbar scoliosis. The study was approved by the Committee of Ethics under the following numbers: FSG/COC 0153 and CAAE 40422114.3.0000.5341.
The degree of disc degeneration was evaluated by magnetic resonance imaging (MRI) according to the Pfirrmann classification, and facet degeneration was determined using the Weishaupt classification. ${ }^{18,19}$

Twenty-three patients were included in the study resulting in the evaluation of 27 IVD.

The IVD were washed with saline solution in the operating block, collected in buffered formaldehyde 10\% ( $\mathrm{pH} \mathrm{7.0),} \mathrm{dehydrated,}$ diaphanized, included in paraffin and cut into $4 \mu \mathrm{m}$ sections in a microtome (Leika). Samples were stained with Hematoxylin and Eosin (Sigma-Aldrich $\left.{ }^{\circledR}\right)$; Safranin O/FCF (Vetec - Sigma-Aldrich $\left.{ }^{\circledR}\right)$; Alcian/PAS pH 2.1 (Sigma-Aldrich ${ }^{\circledR}$ ) and Masson Trichrome (SigmaAldrich $\left.{ }^{\circledR}\right) .{ }^{2,20-23}$ Assays were performed with 5 samples using H\&E and Safranin O/FCF stains to find the best identification of the chondrocyte characteristics in the NP. Thus, based on stain contrast and ease of viewing, the Safranin O/FCF stain was chosen as the most effective one to determine area, diameter and number of chondrocyte clusters. All the study samples were therefore evaluated using this stain.

All analyses were performed in duplicate, using the program Q-Capture 7.0 and the software CellSens Dimension (BX43-Olympus), with the evaluations being performed independently by two researchers with experience in histopathology. The slides were analyzed in $0.5 \mathrm{~cm} \times 0.5 \mathrm{~cm}$ quadrants with more than $90 \%$ of tissue.

The IVD degeneration scores are in accordance with those of other studies. ${ }^{12,20}$ Other, later adaptations of these scores have been reported to define IVD degeneration. ${ }^{24,25}$ In this study, tissues were stained to present a new proposal for degeneration scores, as shown in Table 1, by adapting the scores proposed in a previous work.

\section{Immunohistochemistry}

Initially, sample sections were washed with hydrogen peroxide (3\%) to recover antigens. Non-specific antigens were blocked with bovine serum albumin diluted in PBS $1 \mathrm{X}$. The samples were then incubated with antihuman monoclonal antibody p53, clone BP5312 (Novocastra), prepared at 1:50 dilution in PBS 1X, and with the antihuman monoclonal antibody Ki-67, clone PP-67 (Sigma-Aldrich), prepared at a 1:700 dilution, also in PBS $1 \mathrm{X}$.

The samples were treated with an amplifier (HiDef Detection Amplifier Mouse \& Rabbit - Cell Marque) followed by the detection polymer (HiDef Detection HRP Polymer Detector - Cell Marque). The materials were stained using DAB (Diaminobenzidine-Cell Marque) and counterstained with Harris Hematoxylin.2,26 The images were obtained in duplicate, using the program Q-Capture 7.0 (BX43-Olympus), and analyzed independently by two experienced researchers. For this assay, the tissues were considered as a whole, characterizing percentages. The chondrocyte clusters with protein expression (Ki-67 and p53) were determined by the presence of at least one nucleus stained with DAB. The evaluation was performed on 15 IVD from 15 patients.

\section{Statistical analysis}

Statistical analysis was carried using the program SPSS 22.0. The analysis was performed by correlating non-parametric data using the Spearman-Rho (two-tailed) coefficient, taking into account levels of significance of 0.05 and 0.01 . To analyze the four patients who presented the two levels of significance, the averages of all the variables were calculated for statistical use.

\section{RESULTS}

Analyzing the descriptive data for the patients, there was a prevalence of women, with a ratio of 1:1.44. The ages of the participants with LDD ranged from 28 to 76 years (average age 52 years). 
Table 1. Degeneration scores for the histological stains.

\begin{tabular}{|c|c|c|}
\hline Stain & Purpose & Score-histology \\
\hline \multirow{17}{*}{$\begin{array}{l}\text { Hematoxylin } \\
\text { and Eosin }\end{array}$} & \multirow{4}{*}{$\begin{array}{l}\text { Number of chondrocyte } \\
\text { clusters in the NP }\end{array}$} & 0-Absence \\
\hline & & $1-U p$ to $50 \%$ \\
\hline & & $2-50 \%$ up to $80 \%$ \\
\hline & & $3->80 \%$ \\
\hline & \multirow{5}{*}{$\begin{array}{l}\text { Mean horizontal line } \\
\text { of the chondrocyte } \\
\text { clusters in the NP }\end{array}$} & 0-Absence \\
\hline & & $1-U p$ to $9 \mu m$ \\
\hline & & $2->39 \mu \mathrm{m}$ up to $59 \mu \mathrm{m}$ \\
\hline & & $3->59 \mu \mathrm{m}$ up to $79 \mu \mathrm{m}$ \\
\hline & & $4->79 \mu \mathrm{m}$ \\
\hline & \multirow{6}{*}{$\begin{array}{l}\text { Area of chondrocyte } \\
\text { clusters in the NP }\end{array}$} & 0-Absence \\
\hline & & $1-U p$ to $1500 \mu m^{2}$ \\
\hline & & $>1500 \mu \mathrm{m}^{2}$ up to $2500 \mu \mathrm{m}^{2}$ \\
\hline & & $>2500 \mu \mathrm{m}^{2}$ up to $3500 \mu \mathrm{m}^{2}$ \\
\hline & & $>3500 \mu \mathrm{m}^{2}$ up to $4500 \mu \mathrm{m}^{2}$ \\
\hline & & $>4500 \mu \mathrm{m}^{2}$ \\
\hline & \multirow{2}{*}{ Fissure in the $\mathrm{AF}$} & 0-Absence \\
\hline & & 1-Presence \\
\hline \multirow{14}{*}{$\begin{array}{l}\text { Safranin } \\
\text { O/FCF }\end{array}$} & \multirow{4}{*}{$\begin{array}{l}\text { Number of chondrocyte } \\
\text { clusters in the NP. }\end{array}$} & 0-Absence \\
\hline & & $1-U p$ to $50 \%$ \\
\hline & & $2-50 \%$ up to $80 \%$ \\
\hline & & $3->80 \%$ \\
\hline & \multirow{4}{*}{$\begin{array}{l}\text { Mean Horizontal Line } \\
\text { of the chondrocyte } \\
\text { clusters in the NP }\end{array}$} & 0-Absence \\
\hline & & 1- Up to $39 \mu m$ \\
\hline & & $2->39 \mu \mathrm{m}$ up to $59 \mu \mathrm{m}$ \\
\hline & & $3->59 \mu \mathrm{m}$ up to $79 \mu \mathrm{m}$ \\
\hline & \multirow{6}{*}{$\begin{array}{l}\text { Area of the chondrocyte } \\
\text { clusters in the NP }\end{array}$} & 0-Absence \\
\hline & & 1-Up to $1500 \mu m^{2}$ \\
\hline & & $2->1500 \mu m^{2} u p$ to $2500 \mu m^{2}$ \\
\hline & & $3->2500 \mu^{2}$ up to $3500 \mu^{2}$ \\
\hline & & 4->3500 $\mu \mathrm{m}^{2} \mathrm{up}$ to $4500 \mu \mathrm{m}^{2}$ \\
\hline & & $5->4500 \mu \mathrm{m}^{2}$ \\
\hline \multirow{4}{*}{$\begin{array}{l}\text { Alcian/PAS } \\
(\mathrm{pH} 2.1)\end{array}$} & \multirow{4}{*}{$\begin{array}{l}\text { Acid mucopolysaccharide } \\
\text { deposit around } \\
\text { the chondrocyte } \\
\text { clusters in the NP }\end{array}$} & 0-Absence \\
\hline & & 1-Rare \\
\hline & & 2-Average \\
\hline & & 3-Abundant \\
\hline \multirow{4}{*}{$\begin{array}{l}\text { Masson } \\
\text { Trichrome }\end{array}$} & \multirow{4}{*}{$\begin{array}{l}\text { Misalignment of the } \\
\text { Collagen fibers around } \\
\text { the clusters in the NP }\end{array}$} & 0-Absence \\
\hline & & 1-Rare \\
\hline & & 2-Average \\
\hline & & 3-Abundant \\
\hline
\end{tabular}

Fissures in the AF were observed in $80 \%$ of the IVDs, making this characteristic an important histological factor related to LDD.

Correlation of results between the histological staining of the paired section of IVD of patients with LDD, using H\&E and Safranin O/FCF showed, with the H\&E stain, a positive correlation between the average scores diameters and the scores number of chondrocyte clusters in the NP. However, with the Safranin O/FCF stain, a positive correlation was found between the scores for area and the scores for diameter of the chondrocyte clusters in NP. Safranin O/FCF allowed better visualization of the disc degeneration scores. Figure 1 shows IVD with degeneration in patients with LDD, comparing area and diameter by H\&E (1A) and Safranin O/FCF stains (1B).

Analyzing the total of the samples studies, as shown in Table 2, the Safranin O/FCF stain showed a positive correlation for the three main variables evaluated in this study (number, area and diameter of the chondrocyte clusters in NP).

Table 2 shows a correlation between the clinical and radiological variables and the different forms of histological staining. The muscle strength, pain, variables of patients with LDD were positively correlated. A positive correlation was found between the Masson Trichrome stain and the average scores of the area of chondrocyte clusters in the NP stained with Safranin O/FCF. A positive correlation was also found between the Alcian/PAS stain and the scores for number of chondrocyte clusters in the NP stained with Safranin O/FCF.

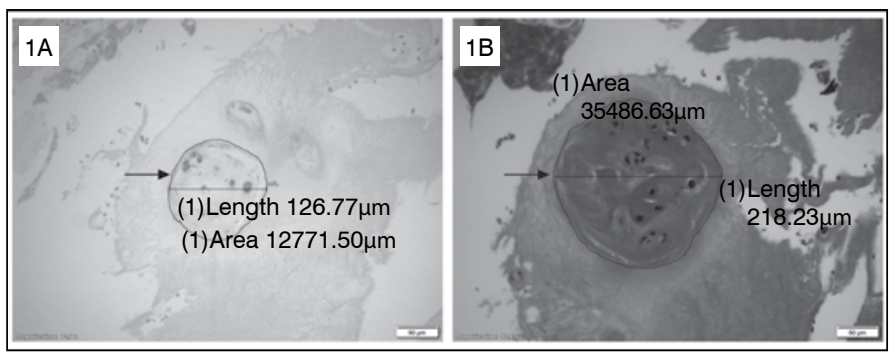

Figure 1. Images of IVD with degeneration in patients with LDD, comparing area and diameter of the chondrocyte clusters in the NP with H\&E (1A) and Safranin O/FCF stains (1B). (200X Lens). The arrows point to the chondrocyte clusters in the NP.

The evaluation of the stains used in this work to determine the IVD degeneration scores in LDD, and the histological patterns of normal IVD in stains performed in the study, are shown in Figure 2.

A positive correlation was found between the degree of IVD degeneration and the time of evolution of the disease. The patients with grade 5 LDD had a longer time of evolution of the disease, while those with grade 2 LDD presented a time of evolution of the symptoms of up to 60 days. The time of evolution of the disease in patients with grade 3 LDD was around 160 days, while for those with grade 4 LDD, evolution of the disease took up to 730 days. The grade 4 LDD was the most diversified group. Therefore there was a clear trend towards increased severity of LDD as the time of evolution of the disease increased. (Figure $3 \mathrm{~A}$ )

Through statistical analyses, the data present a correlation between the degree of IVD degeneration, age group, and degree of facet degeneration, as shown in Figure 3B. Thus the patients with grade 5 IVD degeneration presented grades 3 and 4 facet degeneration and were between 60 and 70 years of age, while the patients with grade 2 IVD degeneration presented grade 2 facet degeneration, and belonged to the younger age group, 30 years. The patients with grades 3 and 4 IVD degeneration were distributed among grades 1 and 4 facet degeneration, and between 30 and 70 years of age.

The score for number of chondrocyte clusters in NP presented a variation in distribution compared to the score for the average area and diameter, although there was a positive correlation. However, there is a clear tendency for these variables to increase together. The higher the number, the larger the area and diameter of the chondrocyte clusters in the NP stained by Safranin O/FCF. (Figure 3C)

A correlation was seen between the Alcian/PAS and Masson Trichrome stains and the score for the number of chondrocyte clusters in NP, stained with Safranin O/FCF. The higher the number of clusters (>80\%) in the Safranin O/FCF stain, the greater the misalignment of the collagen and acid mucopolysaccharide deposits around the chondrocyte clusters in NP (average to abundant score for Alcian/PAS and Masson Trichrome). These data are relevant because it is possible to combine the three stains, in order to accurately determine the severity of LDD. (Figure 3D)

The immunohistochemical evaluation resulted in $73.33 \%$ positive expression for proteins Ki-67 and also for p53. (Figure 4) It should be highlighted that the only sample with a degree of degeneration 5 of the IVD evaluated by immunohistochemistry did not present an expression of protein $\mathrm{Ki}-67$, but presented $100 \%$ positive expression for protein p53.

\section{DISCUSSION}

Most of the histological studies performed involve differentiation of the AF degeneration from NP. ${ }^{27,28}$ In the IVDs studied, the main characteristic of AF was the high percentage of fissures. This specific aspect had been previously described in the literature. ${ }^{20,24}$ However, the findings in NP appear to be more closely correlated with the severity of disc degeneration.

Many studies have demonstrated histological changes of IVD based on specialized degeneration scores. ${ }^{12,20,24,25}$ The present work 
Table 2. Statistical correlation of the variables studied in this work.

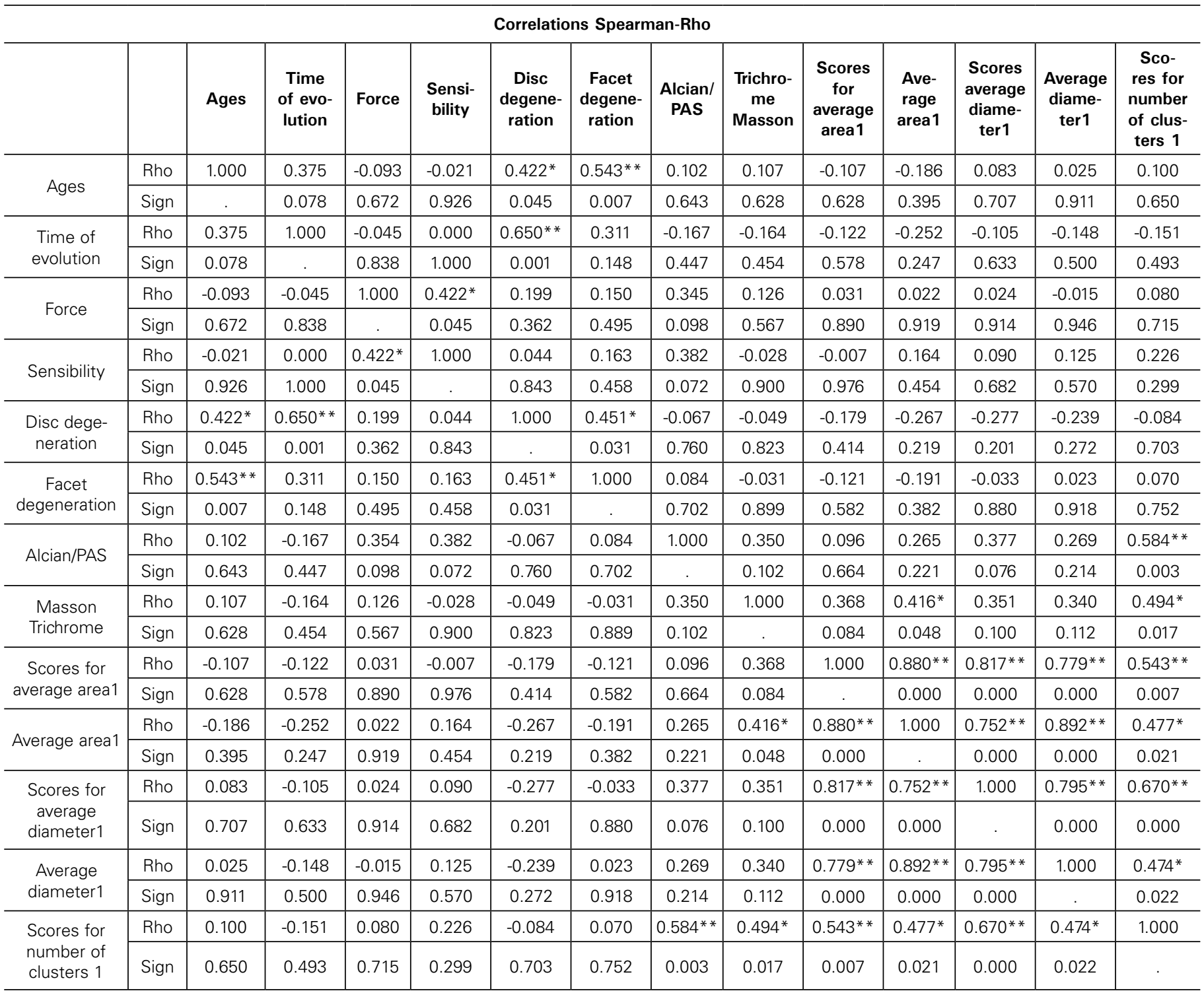

${ }^{1}$ Safranin O/FCF. * Correlation is significant at 0.05 (2 ends). ${ }^{* *}$ Correlation is significant at 0.01 level (2 ends).
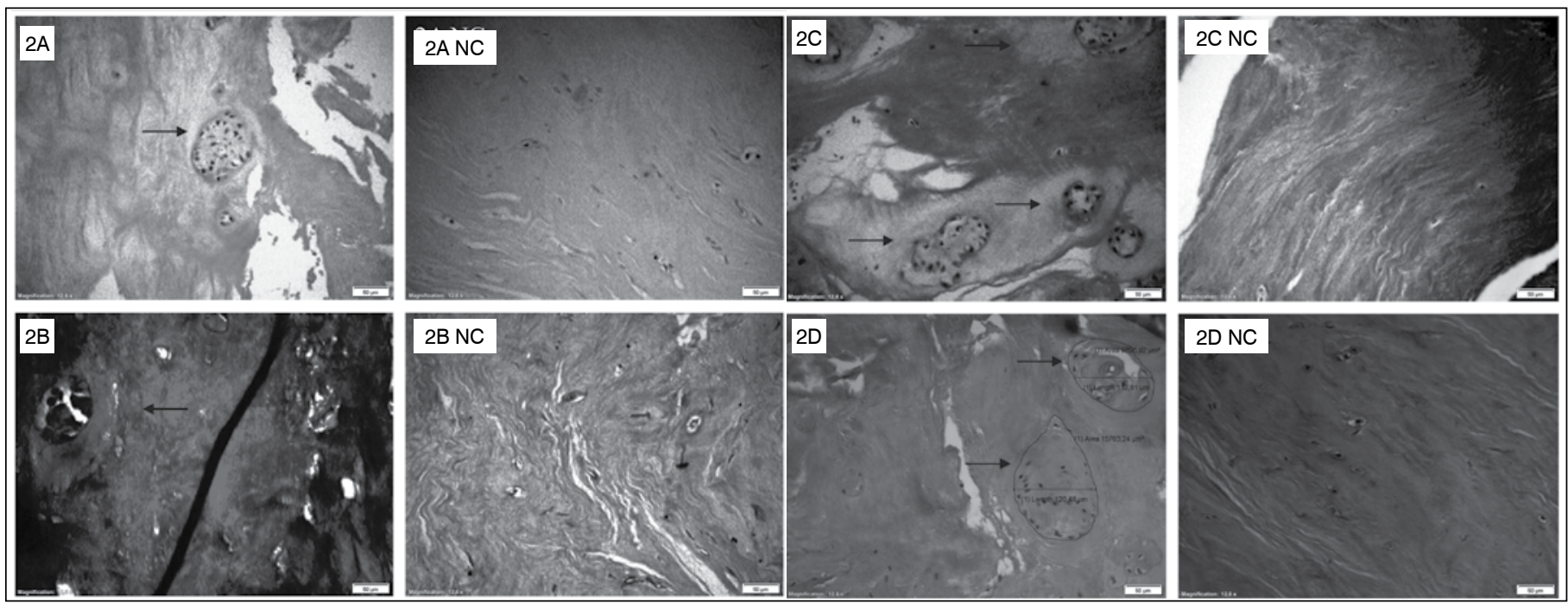

Figure 2. Images of IVD with degeneration in patients with LDD, in the stains used to evaluate the degeneration scores. 2A- H\&E. 2B- Alcian/PAS. 2CMasson Trichrome. 2D- Safranin O/FCF. 2ANC, 2BNC, 2CNC and 2DNC- Negative control (200 X Lens). The arrows indicate the chondrocyte clusters in the NP with the characteristics of each stain. 


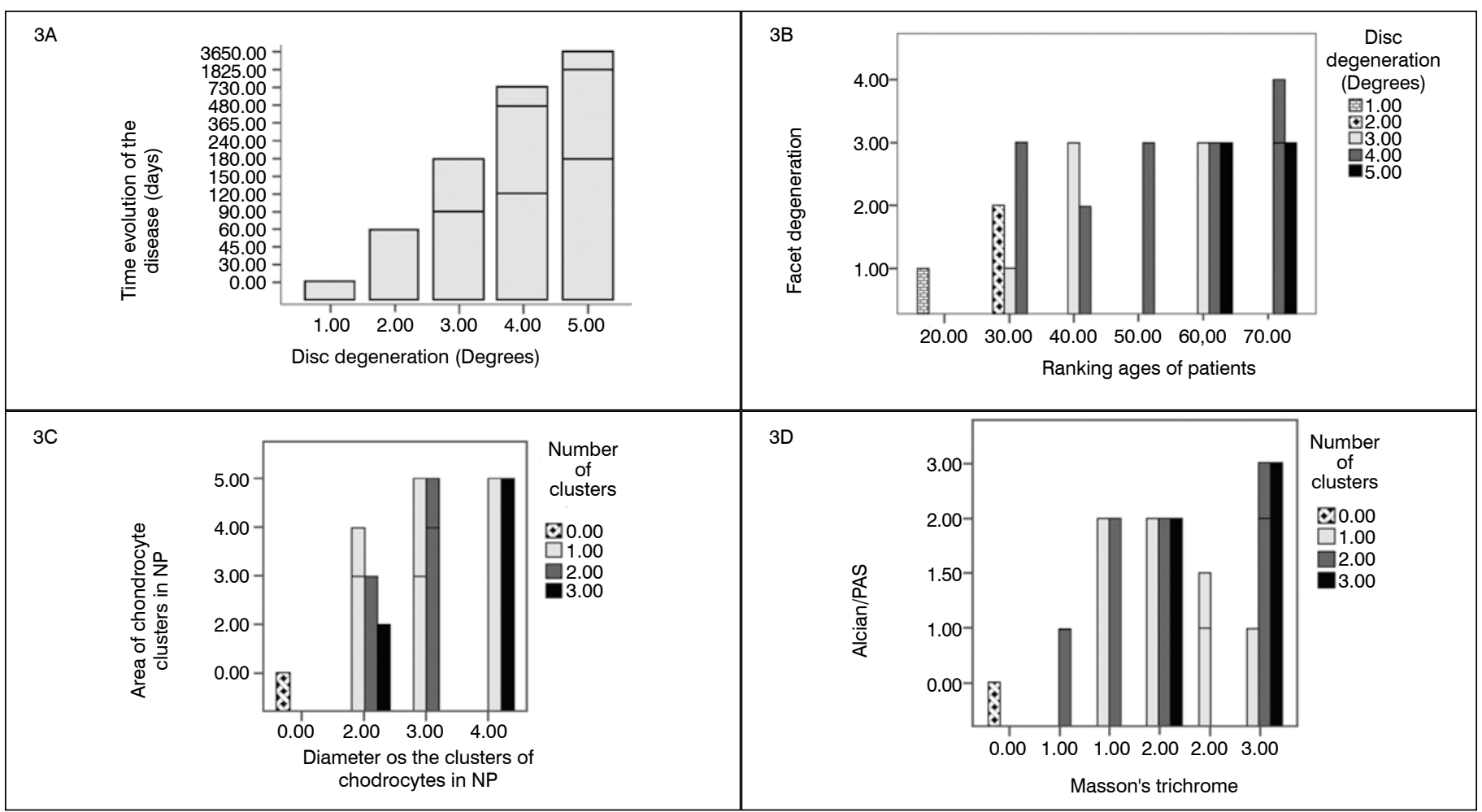

Figure 3. (A) Correlation between degree of LDD and time of evolution of the disease. (B) Correlation between degree of IVD and degeneration, age group, and degree of facet degeneration. (C) Correlation between number, area and diameter of chondrocyte clusters in the NP stained with Safranin O/FCF. (D) Correlation between the Alcian/PAS, Masson Trichrome and Safranin O/FCF stains - score for the number of chondrocyte clusters in the NP.
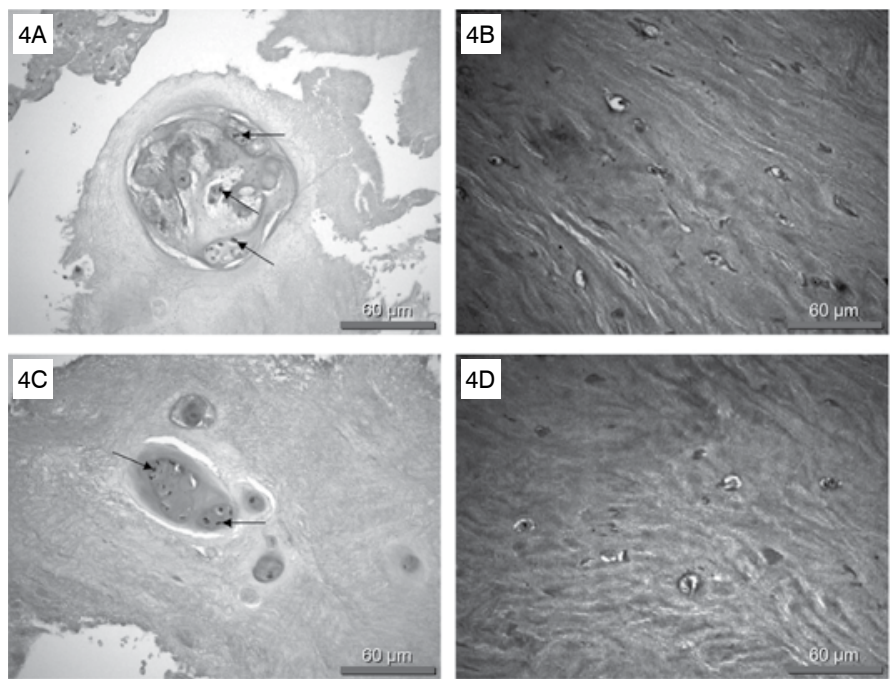

Figure 4. Protein expression in the analysis of immunohistochemistry in degenerated IVD. 4A-Anti-Ki-67 antibody. 4B-Anti-p53 antibody. 4ANC and 4BNC-Negative control (200X lens). The arrows indicate the nuclei with positive expression for the proteins studied in the chondrocyte clusters in the NP, with the characteristics of each stain.

adapted the degeneration scores for LDD, associating the histological characteristics of IVD with the patient's clinical and radiological findings. It was possible to further improve on the characteristics of specialized degeneration scores used for LDD found in previous works using four stains. ${ }^{12,24,25}$ In the study, it was concluded that the more marked changes are in the NP, and that fissures and other characteristics of AF degeneration are usually overestimated. There remains a degree of imprecision in the determination of LDD by the specialized degeneration scores, despite the adaptations made in an attempt to optimize and identify the histological state of the IVD evaluated and the patient's clinical classification, and to determine the degree of LDD by the specialized biomarkers of the degeneration scores defined in this study.

LDD is a multifactorial disease: smoking, sedentary lifestyle, obesity, excessive physical effort, age, sex, height, psychological factors, occupational exposure and genetics have all been associated with the disease. ${ }^{6,24}$ For this reason, determining a few descriptive characteristics of the patient does not help determine the correlation of the disease. Sex, smoking and diabetes were not considered to be statistically related to the disease in this study, unlike the finding of other authors. ${ }^{6,24}$ Histological evaluation shows that disc degeneration occurs in the first years of adolescence.12,29 This fact is explained by the environmental variation and characteristics of modern lifestyle habits, whereby young people are more obese and more sedentary, and work routines are different from those of the past.

The results of this study showed a prevalence of this pathogeny in young women who have had the disease for only a short time. ${ }^{4,20}$ Thus, there is a clear justification for clinical studies and basic research on LDD for worldwide public health, in order to improve understanding of the disease and obtain greater investments in preventive medicine.

This study demonstrated that some clinical characteristics of the patient are important to understand the histology of the disease. Factors such as age, force, sensibility, time of evolution of the disease, and imaging to determine the degrees of disc and facet degeneration were correlated with high specialized scores of degeneration using different stains.

The results enabled the definition of the importance of combining stains to define the severity of the disease. The acid mucopolysaccharide deposit (Alcian/PAS) around the chondrocyte clusters in the NP, and the misalignment of collagen fibers (Masson Trichrome) close to the chondrocyte clusters in NP, are related to area, diameter and number of chondrocyte clusters in NP (Safranin O/FCF). In addition, the use of H\&E and Alcian/PAS enabled identification of the characteristics of increased cell density and proliferation of chondrocytes, fissures and deposits of acid mucopolysaccharides around the chondrocyte clusters in NP. Similar findings were corroborated by the literature. ${ }^{30}$ 
The choice and definition of the Safranin O/FCF stain was essential to determine the characteristics of IVD degeneration in NP and its relationship with other stains and the different degeneration factors used for LDD. The same stain was used in the past to determine the chondrocyte clusters in the NP.2,31

The present study showed that the Safranin O/FCF stain was best one for histopathological evaluations involving LDD, because it allows greater accuracy of the results, as it is easy to delimit the chondrocyte clusters in the NP.

According to the data obtained with immunohistochemistry, IVD degeneration occurs in two stages, regeneration and apoptosis. Tissue revitalization was verified by the increased expression of cell proliferation markers resulting from the increased cell density, forming the chondrocyte clusters. The other phase was followed by increased expression of cell apoptosis markers. . $^{5,12,16,17}$

\section{CONCLUSIONS}

This work identified the importance of the joint use of H\&E, Alcian/PAS, Masson Trichrome and Safranin O/FCF stains to determine the disease severity and to define the disc degeneration scores. Among the stains evaluated in the study, Safranin O/FCF was superior for visualizing the morphological characteristics of
IVD degeneration. The simplicity and feasibility of the definition of specialized scores for degeneration used to determine the degree of severity of the LDD can be proposed in the clinical routine. The new classification allowed a more precise correlation of the degenerative characteristics of IVD with the clinical-radiological information about the patient. Moreover, it was possible to infer the existence of two stages in the IVD degeneration process in LDD: increased cell proliferation, with the formation of chondrocyte clusters, followed by increased expression of cell apoptosis markers.

\section{ACKNOWLEDGMENTS}

This study was supported by development agencies that promote research and provide grants: Conselho Nacional de Desenvolvimento Científico e Tecnológico (CNPq) 150900/20147, Fundação de Coordenação de Aperfeiçoamento de Pessoal de Nível Superior (CAPES), Fundação de Amparo a Pesquisa do Rio Grande do Sul (FAPERGS) and AOSpine Latin America.

All the authors declare that there are no conflicts of interest regarding this article.

CONTRIBUTIONS OF THE AUTHORS: Each author contributed individually and significantly to the development of the manuscript. MPF, AF and JAPH were the main contributors in the execution of the work and scientific writing. ISA was the Scientific Initiation student involved in the project execution. AF was the researcher responsible for the operation, monitoring of patients and gather clinical data. SE was the researcher responsible for the evaluation of the data of the statistical analysis. SP, DCM, MRE, SE, AF and JAPH did also the revision of the paper and contributed to the concept of the study.

\section{REFERENCES}

1. Waddell G. Low back pain: a twentieth century health care enigma. Spine (PhilaPa 1976).1996;21(24):2820-5

2. Iwashina T, Mochida J, Sakai D, Yamamoto Y, Miyazaki T, Ando K, Hotta T.Feasibility of using a human nucleus pulposus cell line as a cell source in cell transplantation therapy for intervertebral disc degeneration. Spine (PhilaPa1976). 2006;31(11):1177-86.

3. Hall RA, Kang JD. Degeneration, repair, and regeneration of the intervertebral disc. Curr Opin Rheumatol. 2000:11:413-20.

4. Luo X, Pietrobon R, Sun SX, Liu GG, Hey L. Estimates and patterns of directhealth care expenditures among individuals with back pain in the United States. Spine (PhilaPa 1976). 2004;29(1):79-86.

5. Zhao CQ, Wang LM, Jiang LS, Dai LY. The cell biology of intervertebral discaging and degeneration. Ageing Res Rev. 2007;6(3):247-61.

6. David G, Ciurea AV, Mitrica M, Mohan A. Impact of changes in extracellular matrix in the lumbar degenerative disc. J Med Life. 2011;4(3):269-74.

7. Walker MH, Anderson DG. Molecular basis of intervertebral disc degeneration. Spine J. 2004;4(6 Suppl):158S-166S.

8. Kim KW, Lim TH, Kim JG, Jeong ST, Masuda K, An HS. The origin of chondrocytes in the nucleus pulposus and histologic findings associated with the transition ofa notochordal nucleus pulposus to a fibrocartilaginous nucleus pulposus in intactrabbit intervertebral discs. Spine (PhilaPa 1976). 2003;28(10):982-90.

9. Kim KW, Kim YS, Ha KY, Woo YK, Park JB, Park WS, et al. An autocrine orparacrine Fas-mediated counterattack: a potential mechanism for apoptosis ofnotochordal cells in intact rat nucleus pulposus. Spine (PhilaPa 1976). 2005;30(11):1247-51.

10. Roberts S, Menage J, Duance V, Wotton S, Ayad S. 1991 Volvo Award in basicsciences. Collagen types around the cells of the intervertebral disc and cartilage end plate: an immunolocalization study. Spine (PhilaPa 1976). 1991;16(9):1030-8.

11. Gruber HE, Norton HJ, Ingram JA, Hanley EN Jr. The SOX9 transcription factor in the human disc: decreased immunolocalization with age and disc degeneration. Spine (PhilaPa 1976). 2005;30(6):625-30.

12. Boos N, Weissbach S, Rohrbach H, Weiler C, Spratt KF, Nerlich AG. Classification of age-related changes in lumbar intervertebral discs: 2002 Volvo Award in basic science. Spine (PhilaPa 1976). 2002;27(23):2631-44

13. Adams MA, Roughley PJ. What is intervertebral disc degeneration, and what causes it? Spine (PhilaPa 1976). 2006;31(18):2151-61

14. Nomura T, Mochida J, Okuma M, Nishimura K, Sakabe K. Nucleus pulposusallograft retards intervertebral disc degeneration. Clin. Orthop. Relat. Res. 2001;(389):94-101.

15. Johnson WE, Evans H, Menage J, Eisenstein SM, El Haj A, Roberts S. Immunohistochemical detection of Schwann cells in innervated and vascularizedhuman intervertebral discs. Spine (PhilaPa 1976). 2001;26(23):2550-7.

16. Sakai D, Mochida J, Yamamoto Y, Nomura T, Okuma M, Nishimura K, et al. Transplantation of mesenchymal stem cells embedded in Atelocollagen gel to the intervertebral disc: a potential therapeutic model for disc degeneration. Biomaterials. 2003;24(20):3531-41.

17. Zhao CQ, Jiang LS, Dai LY. Programmed cell death in intervertebral discdegeneration. Apoptosis. 2006;11(12):2079-88

18. Pfirrmann CW, Metzdorf A, Zanetti M, Hodler J, Boos N. Magnetic resonance classification of lumbar intervertebral disc degeneration. Spine (PhilaPa 1976). 2001;26(17):1873-8.

19. Weishaupt D, Zanetti M, Boos N, Hodler J. MR imaging and CT in osteoarthritis of the lumbar facet joints. Skeletal Radiol. 1999;28(4):215-9.

20. Sive JI, Baird P, Jeziorsk M, Watkins A, Hoyland JA, Freemont AJ. Expression of chondrocyte markers by cells of normal and degenerate intervertebral discs. MolPathol. 2002;55(2):91-7.

21. Quintarelli G, Scott JE, Dellovo MC. The chemical and histochemical properties of Alcian Blue. II. Dye binding of tissue polyanions. Histochemie. 1964;4(2):86-98.

22. Scott JE, Quintarelli G, Dellovo MC. The chemical and histochemical properties of Alcian Blue. I. The mechanism of Alcian Blue staining. Histochemie.1964;4(2):73-85.

23. Rufai $A$, Benjamin $M$, Ralphs JR. The development of fibrocartilage in the rat intervertebral disc. AnatEmbryol (Berl). 1995;192(1):53-62

24. Weiler C, Lopez-Ramos M, Mayer HM, Korge A, Siepe CJ, Wuertz K, et al. Histological analysis of surgical lumbar intervertebral disc tissue provides evidence for an association between disc degeneration and increased body mass index. BMC Res Notes. 2011:4:497.

25. Rutges JP, Duit RA, Kummer JA, Bekkers JE, Oner FC, Castelein RM, et al. A validated new histological classification for intervertebral disc degeneration. Osteoarthritis Cartilage. 2013;21(12):2039-47.

26. Bisgaard K, Pluzek KJ. Watersoluble polymer conjugates for enzyme immuno assays. 10th International Congress of Histochemistry and Cytochemistry, August18-23,1996, Kyoto, Japan. ActaHistochem Cytochem;1996 (Suppl)29:738-9.

27. Yasuma T, Makino E, Saito S, Inui M. Histological development of intervertebral disc herniation. J Bone Joint Surg Am. 1986:68(7):1066-72.

28. Harada Y, Nakahara S. A pathologic study of lumbar disc herniation in the elderly. Spine (PhilaPa 1976). 1989;14(9):1020-4.

29. Haefeli M, Kalberer F, Saegesser D, Nerlich AG, Boos N, Paesold G. The courseof macroscopic degeneration in the human lumbar intervertebral disc. Spine (PhilaPa 1976). 2006;31(14):1522-31.

30. Weiler C, Nerlich AG, Zipperer J, Bachmeier BE, Boos N. 2002 SSE Award Competition in Basic Science: expression of major matrix metalloproteinases is associated with intervertebral disc degradation and resorption. Eur Spine J. 2002;11(4):308-20.

31. Schell H, Lienau J, Kleemann RU, Schlichting K, Taylor WR, Weiler A, et al. Crushed bone grafts and a collagen membrane are not suitable for enhancing cartilage quality in the regeneration of osteochondral defects - an in vivo study in sheep. J Biomech. 2007;40(Suppl 1):S64-72 